\title{
Post-Islamism: The New Face of Political Islam in Indonesia
}

\author{
Muchammad Nur Huda \\ IAI Al-Khoziny Sidoarjo, Indonesia
}

\begin{abstract}
The movement of Islamic politics in post- Islamism is movement ideology in the discourse of contemporary Islamic studies in Indonesia are being crowded discussed. PostIslamism first time emerged as the face of Islam political supporters of the ideology of Islamism in contestation election of the general governor of Jakarta in 2017 through action to defend Islam on $2^{\text {nd }}$ December 2016 or what is known as the 212 movements. This article examines the emergence of post-Islamism as the new face of political Islam in Indonesia and how postIslamism is built into a "new manifesto" in the Political Islam movement in Indonesia, based on the reading of political, anthropological theory. The method that is used is a literature review by using primary data and secondary. Results of the study showed that the movement of political Islam, post-Islamism, still needs further research and comprehensive. The term post- Islamism has not uncovered the basic facts about how the terms of the force lived and could become the ideological basis for the movement of Islam politics itself.
\end{abstract}

Keywords: post- Islamism; Islam; political

\section{INTRODUCTION}

The emergence of the term post-Islamism as an ideological movement in the discourse of contemporary Islamic studies, especially in Indonesia, seems increasingly interesting to discuss. The appearance of the faces of political Islam who bear the ideology of Islamism in support of the contestation the governor's choice in the Jakarta with the Action to Defend Islam III movement on December 2, 2016, which is better known as the 212 movement, and the astonishing fact that the victory of electoral politics is on their side, raises a confusing and confusing political analysis. full of anomalies. So far, Islamism as a platform for the movement of political parties such as PKS (Partai Keadilan Sejahtera), for example, seen by people as " a right-line Islamic party that simply accepts the democratic system as a tactic to achieve its ideological or Islamic ideals " (Bektisiwi, 2019; Wahono, 2018).

It was Sohibul Umam, the PKS president who made an interesting statement when attending the Prabowo-Sandiaga Uno declaration, that the vice presidential candidate they were carrying was a prototype of the post-Islamism era santri. Sandiaga Uno, according to him, has experienced spiritualization and Islamization so that he is worthy of being an ideal santri figure in the millennial era. Inevitably, the PKS presidential statement sparked discussion among academics and political 
observers, from those who took it seriously to considering the statement as a joke and a fake tactic to gain votes in the 2019 presidential election contes (Ashgar, 2015).

The question is: is it true that post-Islamism as a new narrative manifesto of political Islam that transcends Islamism-extremism really occurs in Indonesia? The term post-Islamism was originally put forward by Asep Bayat to explain the shift in discourse in Iranian society in the 1990s. He explained the significant growth of metamorphosis among Iranian Muslim intellectuals who prefer inclusive religious attitudes by promoting the country without neglecting ethics (Bayat,2011). which he then expands with a comprehensive discussion by making comparisons with Egypt.

In the context of Iran's post-Islamism narrative, Bayat aims at three social fragments: changes in the architecture and social order of urban communities in Tehran since the leadership of Mayor Gholamhosain Karbaschi, the emergence of a new intellectual movement transformation led by Abdul Karim Soroush and Mohammad Khatami, and new currents. " Muslim feminists " in Iran. This movement then gained momentum through the election of Khatami as President of Iran, although it was also faced with limitations due to prolonged friction with more conservative groups (Bayat,2011).

Meanwhile in Egypt, Islamist movements began to open new channels of religious activism after being banned from politics by Gamal Abdel Nasser and Anwar Sadat. As a consequence, they tended to draw Egypt closer to Islam through completely apolitical channels, for example through the expansion of da'wah to an increasingly pious elite level, control of professionals and entrepreneurs, as well as the discourse of " pluralism " in Islamic society. This phenomenon raises at least two things: the development of the current "propaganda popular "which makes the symptoms of religiosity in the society without having to go through the state, and the rise of a new generation of Muslim Brotherhood to become familiar with the discourse of democratization, human rights, to the articulation of " propaganda " just in circles professionals and civil society.

In Indonesia, some scholars have put different perspectives in facing this postIslamism. Ariel Heryanto, say, looking at the post-Islamism manifested in the emergence of a new visual culture among young Muslims in the early 21st century, at least through the emergence of the films " Islami " which began to pack bioskop- cinema homeland (Heryanto, 2015). Noorhaidi Hasan and Mohammad Ansor, from different perspectives, argue that post-Islamism is born from changes in the structure of the public sphere in Indonesia, which is reflected in the large variety of organizing and expressions of diversity among Muslim youth in Indonesia.

If the PKS statement can really be accounted for in an acedemic-cultural manner, then the basic assumptions or more precisely the concerns of some groups that the developing Islamic narrative leads to radicalism, intolerance and other banal activism that is contrary to the climate of democracy, will find its momentum to change. and appear in a moderate style as the mainstream Islamic movement in Indonesia.

By departing from the above framework, this paper will author a frame with a focus on the study of how post-Islamism is built into a "new manifesto" in the political Islam movement in Indonesia, based on the reading of political anthropological theory. 


\section{METHOD}

The method used in this study is the literature review. Literatures used include books, articles, and trusted sites. By comparing various exposures from the literature, the authors analyze, identify and review to produce a more objective view of post- Islamism in Indonesia.

\section{RESULT AND DISCUSSION}

\section{Post-Islamism: Theoretical Struggles}

As the author has alluded to earlier, the term post-Islamism was first introduced theoretically by Asep Bayat, an expert in Iranian political sociology, who coined the term through an essay in " Middle East Critique " in 1996. But in Indonesia, the meaning of post-Islamism as a movement orientation experiences multiple interpretations. Hans Abdiel Harmakaputra, quoting Noorhaidi Hassan's view, pointed out that post-Islamism does not only apply in the realm of political pragmatism (Harmakanto, 2015), but it is also linked with the views of several Liberal Islamic think-tanks, The Wahid Institute, and several other Islamic organizations that proclaim the urgency of orientation and new strategies to present Islam in the public sphere. For them, embodying Islam into the public sphere does not have to be confronted vis-a-vis universal dogmas such as human rights, freedom of opinion, good governance, and other aspects contained in the teachings of democracy (Hasan, 2013).

It is in this non-political context, according to Atmari, the term post-Islamism in Indonesia is indeed more diverse and tends not to be easily framed. He gave an example, for example, the discourse on the Islamic Defenders Front (FPI) which stated that organizationally they accept the Republic of Indonesia, but at the same time tend to impose the implementation of formal enforcement of Islamic law. Or like the Hizbut Tahrir Indonesia group which states that NKRI is Dead Price, but they promote the Islamic caliphate as its constitutional system (Nadjib, 2017). The diversity of interpretations and coverage of the term post-Islamism is perhaps because theoretically, it is indeed broad, as the originator expressed it. Asep Bayat wrote:

"Not only a condition, post-Islamism is also a project, a conscious to conceptualize and strategies the rationale and modalities of transcending Islamism in social, political, and intellectual domains. Yet, post-Islamism is neither anti-Islamist nor un-Islamist or secular. Post-Islamism represents an endeavor to fuse religiosity with right, faith, and freedom. Islam and civil liberties and focus on rights instead duties, plurality instead of singular authority, historicity than fixed and rigid interpretation of scriptures, and the future than rather than the past" (Bayat, 2013).

It can be seen from Bayat's quote above that post-Islamism is not merely a political domain, but includes all aspects of theoretical and practical struggles, in the context of how Islam should be able to present a significant influence on the order of people's lives, escalation of power, and one's intellectuality. In this sense, the Post-Islamist group is not only embedded for those who exhaust their energy and thoughts of thinking about pragmatic political strategies alone, but also 
applies to those who are able to contribute in reconstructing and projecting Islamic attitudes based on the theoretical reinterpretations they embrace.

Genealogically, according to Amika Wardhana, as quoted by Akhmad Muawal Hasan, the origin of the term post-Islamism can actually be traced back to the old generation of Islamist groups. Formally they want to apply symbols to the rules according to Islamic law in a modern country. There are two paths taken by this Islamist group, first, those who choose a ceasefire like the ISIS group, and second, those who stay away from the path of extremism such as Islamist groups in Pakistan or Muslim-majority countries. Masyumi and his successor parties are in the second group, namely participating in contesting on the Indonesian democracy platform. "Unfortunately, " according to Amika, " this Islamist group failed. Many have lost political battles. The descendants who carry the same vision also have the same fate. Some even chose the option of violence" (Hasan, 2018).

The reason, according to Amika, by quoting Bayat, was that Islamist groups had consolidated solidly to the grassroots level and then won the seat of power. But in turn they become complacent. When they are at the peak of power, they forget the main task of a country, namely to encourage and create people's welfare. As happened in other Muslim majority countries, Islamist groups in Iran, as in the case of Bayat's initial research, then realized and changed themselves, and softened on the basis of the realities of today's society.

The soft stance of the old Islamists shows that the main distinction of post-Islamism, based on the historical tracing above, is compromise. Islamists no longer boast about shouting Islamization campaigns in formal clothes, but focus on promoting more secular issues. The idioms and slogans they echo are relatively more general in nature, such as tolerance, human rights, social justice, economic equity, and so on. This softness of attitudes and views of Islamists is perhaps what led Ulil Absar Abdallah, in his analysis when responding to Bayat's study, to quote Alferd Stepen, a political science expert from the University of Colombia, who coined the term "twin tolerance" (Abdallah, 2018). In other words, post-Islamism refers more to a new style of secularism that is neutral and accommodating, or even gives equitable support to all religions, instead of being hostile to religion as the initial perception of Islamists towards Western-style secularism. In short, post-Islamism is an intimate marriage between Islam and democracy.

The question is - as the author has suggested in the introduction - is it true that Indonesianstyle post-Islamism has invalidated the thesis of Western experts that Islam cannot be compatible with democratic culture? This question is important to ask considering that the statement of postIslamism santri is present in the electoral political contestation space and comes from a party that carries Islamism as its ideological platform. So, the concerns of some circles, such as Ulil, for example, are quite reasonable. Could it be that the term post-Islamism is only a vehicle for political elites who maneuver on opportunistic and pragmatic impulses in order to gain votes from the millennial circles.

\section{Political Islam in Indonesia: The Transition of Islamism to Democracy}

Studying further the theoretical assumptions of how post-Islamism has become a new manifesto of the political Islam movement in Indonesia is not as easy as turning the palm of the hand. This is none other than because the eletoral political climate largely determines the dialectic 
of the journey of democratization. It takes a review of the latest dynamics of political Islam appearing in the public sphere, how they initiate various patterns of their dakwah movements, bringing issues typical of the democratic climate, especially after the reformation era (Hasan, 2008).

The discourse of political Islam in Indonesia has almost always attracted the attention of many circles, even though it is not something new. The reason is, because besides Islam is a religion that is adhered to by the majority of Indonesia's population, it is also a teaching that emphasizes important points of political meaning, which in Islamic legal-formal theory is known as fiqih siyasah (Taj, 1415). Thus, the dialectic between Islam and politics has always been an important note, especially in the historical landscape of Indonesian politics.

The term political Islam, according to Masykuri Abdullah, often appears in discourses regarding the orientation, point of view, and Islamic movements or activities in Indonesia, which are side by side with the terms " cultural Islam " and " structural Islam " (Abdullah, 2011). It means the implementation of Islamic activities through Islamic political parties, which can be identified based on the use of Islamic names, principles, goals and symbols. In the era of parliamentary democracy, the terms structural Islam and political Islam were relatively the same, in which Islamic party leaders supported both. They supported Islamic parties and the establishment of an Islamic system, including support for the idea of Islam as the basis of the state in the Constituent Assembly, which was then dissolved by Presidential Decree on July 5, 1959. Like wise during the New Order era, this condition was still the same. But then that changed, with the New Order government policy regarding the deideologization of political parties and the depoliticization of Islam. In the 1970s and early 1980s, both structural Islam and political Islam received government restrictions, so that cultural Islamic movements and orientations emerged, especially those highlighted by Nurcholis Madjid and Abdurrahman Wahid. Both also tend to reject political Islam and structural Islam.

In the context of electoral politics, the dynamics of the ups and downs of political Islam in Indonesia is an interesting and challenging study. Muhammad Iqbal Ahnaf refutes the belief of analysts who believe that Indonesian Islam, - especially since the 2009 and 2014 elections, shows an astonishing fact where the vote acquisition of Islamic parties (less than 35 percent) is far below that of nationalist parties-- - is no longer a fertile ground for Islamic politics. That the failure of Islamic parties is considered to reflect the end of the era of flow politics in Indonesia (the end of ideology). According to Ahnaf, this condition is considered to be the culmination of the failure of Islamic politics in the history of Indonesian politics which has been fought since before independence. Ahnaf wanted to show that the failure of Islamic parties does not mean the end of Islamic politics. He wrote:

"The progress and decline of Islamic politics is not only shown by the electoral achievements of Islamic parties. Islamic parties are only one variant of the Islamic political struggle. The competition between moderate and radical forces among Muslims is not over. When the communal boundary between moderate and radical is increasingly blurred, while the social role of the mainstream groups weakens, it is not impossible that the map (landscape) of Muslims will change " (Ahnaf, 2016). 
From the quotation above, it appears that Ahnaf was very observant in analyzing the dynamics of political Islam from its electoral aspect. Even at the end of his study, he showed how democracy in Indonesia was actually an opportunity as well as a challenge for the mobilization of radical political Islam (Ahnaf, 2012). Nonetheless, he concludes that "democratization in Indonesia has shown a ripening process that is unlikely to reverse. Therefore, the chances of a revolutionary change by overthrowing democracy and replacing it with an Islamic state are almost impossible (Ahnaf, 2012).

\section{Post-Islamism: Between Compromism and Despair}

If Ahnaf's conclusion can be justified, that democracy has become the most rational choice for political Islam activists, then the claim of the post-Islamism narrative they echo could be a compromise attitude towards the most recent socio-political reality. From the perspective of political communication, in the author's opinion, it is very possible that the election of postIslamism for Islamists as a platform for their movement has been studied based on careful considerations, whether sincere or just pragmatism and opportunistic choices, as Ulil worries above. ----, especially to capture and target the votes of millennial youth. The compromise in the post-Islamist world, according to some observers, has indeed contributed to the confusion of millennials and the younger generation. In a paradoxical language, they can still enjoy modernity and Western pop culture, but they don't have to give up their Islamic identity, including the symbols they wear in public spaces.

From the aspect of the movement and the typology of Islamists' da'wah, for example, we can see how the innovations and styles of clothing worn by " ustadz-ustadz Hijrah " on television and on their various da'wah agendas, are very metal and contemporary, with beards and clothes "Tahliban". The preachers, who have been categorized as the ideal prototype of Islamists with the jargon of formalizing Islamic law, appear by quoting Quranic verses and hadiths, but at the same time, they confidently appear to be models of commercials for beauty and other industrial products. Socialite mothers of the urban elite with their flamboyant dress can stand out and participate in demonstrations in the framework of Islamic defense, but at that time, they are engrossed in taking selfies and enjoying the hedonistic culture of the people of the Capital City.

In such a context, it is not an exaggeration to consider post-Islamism as the last resort to overcome the failure of Islamists to campaign for ideas of Islamic formalization due to the onslaught of capitalism and consumerism that has hit the urban Muslim elite. The slogan of postIslamists to attract the millennial generation, as parodied by Ariel Hariyanto with the phrase " Islam which still allows them to enjoy K-pop", is undeniable. The piety of Indonesian society increased rapidly after the reformation, especially marked by the massive number of religious symbols in the public sphere. It's just that, according to him, in the post-Islamist narrative, Islam and commodification or commercialization go hand in hand with affection. Religion is subject to capitalism and media industrialization.

It seems that the symbol of Islam has always been the most lucrative attraction and political commodity, especially when politics requires greater public legitimacy. In the domain of electoral politics, the election campaign as a manifestation of political communication is also heavily colored by religious symbols. Various political statements seem incomplete until they are complemented by scriptural arguments and delivered by religious figures (Muhtadi, 2005). At this 
point, the author is reminded of one of the famous dictums which in several statements was attributed to Ibn Rushd, that the most profitable commodity in a society steeped in ignorance is the commodification of religion. A person only needs to cover falsehood with a cover of religion, so that society will accept it. It seems that the styles of political communication displayed by Islamists have, in recent times, used the same narrative.

\section{CONCLUSION}

As a discourse in the political Islam movement, post-Islamism actually still needs further and comprehensive analysis. This happens because the term post-Islamism itself, in the discourse of Islamic thought in Indonesia, is relatively unable to reveal basic facts about how it actually applies, lives, and is able to become the ideological basis of the movement. The variety of interpretations raised by experts makes it difficult to study post-Islamism as a whole. It takes more specific study slices and precise aiming, especially if the term post-Islamism is raised in electoral political contestation. If not, the discussion of post-Islamism will only create new confusion, and will not be able to reveal the basic distinction between the post-Islamic narrative and the culture of consumerism-capitalism.

\section{REFERENCES}

Abdullah, Masykuri. (2011). Islam dan Dinamika Sosial Politik di Indonesia. Jakarta: Gramedia Pustaka Utama.

Ahnaf, Muhammad Iqbal. (2016) Tiga Jalan Islam Politik di Indonesia: Reformasi, Refolusi dan Revolusi. Wawasan: Jurnal Ilmiah Agama dan Sosial Budaya. Vol 1 No. 2.

Akhmad Muawal Hasan, "Sandiaga disebut "Santri Post-Islamisme" oleh PKS: Jualan Belaka?, dalam https://tirto.id/sandiaga-disebut-santri-post-islamisme-oleh-pks-jualan-belaka-cRJG, last update 13 Agustus 2018, diakses pada tanggal 23 Nopember 2018, pukul 19.03 WIB.

Ashgar, Ali. (2015). Islam Politik dan Radikalisme: Tafsir Baru Kekerasan Aktivisme Islam Indonesia. Jurnal Keamanan Nasional Vol. I No. 2.

Atmari. Islamisme dan Post-Islamisme Kyai: Memantapkan Nalar dan Sikap Islamisme ala Intelektual Pesantren. Procedings Annual Conference for Muslim Scholar 2, Kopertais Wilayah IV Surabaya.

Bayat, Asef. (2013). "Post-Islamism at Large", in Post-Islamism: The Changing Faces of Political Islam. New York, NY: Oxford University Press.

Bayat, Asep. (2011). Post-Islamisme, terj. Making Islam Democratic: Social Movements and the PostIslamist Turn. Yogyakarta: LkiS.

Bektisiwi, P. (2019). Implementation of democratic values at the Jagad student boarding school 'Alimussirry Surabaya. Journal Intellectual Sufism Research (JISR), 1(2), 23-26.

Harmakaputra, Hans Abdiel. (2015). "Islamism and Post-Islamism "Non-Muslim" in Socio-Political Discourses of Pakistan, the United States, and Indonesia. al Al Jamiah; Journal of Islamic Studies Vol 53 No 1.

Hasan, Noorhaidi. (2013)."Post-Islamist Politics in Indonesia”, in Post-Islamism: The Changing Faces of Political Islam, ed. by Asef Bayat. New York, NY: Oxford University Press. 
Huda, 2021

Hasan, Noorhaidi. (2008). Laskar Jihad, Islam, Militansi, dan Pencarian Identitas di Indonesia Pasca Orde Baru. Jakarta: LP3ES.

Heryanto, Ariel. (2015). Identitas dan Kenikmatan: Politik Budaya Layar Indonesaia. Jakarta: Kepustakaan Populer Gramedia.

Muhtadi, Asep Saeful. (2005). "Dinamika Islam Politik Pasca Orde Baru Perspektif Komunikasi Politik”, dalam Mimbar Volume XXI No. 2.

Nadjib, Emha Ainun. (2017, February 10). Pandawayudha, rubrik Opini. Kompas.

Taj, Abdurrahman. (1415 H). Al-Siya > sah al-Syariyyah wa al-Fiqh Isla >mi. Mesir: Syabakah al-Alu>kah.

Ulil Absar Abdallah, "Revolusi Post-Islamis di Dunia Islam", dalam http://islamlib.com/politik/duniaislam/revolusi-post-islamis-di-dunia-islam/ last update21 November 2011, diakses pada tanggal 23 November 2018 pukul 20.02 WIB.

Wahono, Satrio. (2018 August 13). PKS dan Post-Islamisme. Koran Sindo. 